Fakultas Hukum Universitas Lancang Kuning, Jalan Yos Sudarso KM 8 Rumbai Pekanbaru, Riau, Kode Pos 28266. Telp: (+62761)-51877

E-mail: jurnal.respublica@ac.id

Website: https://journal.unilak.ac.id/index.php/Respublica

\title{
Kewajiban Pengusaha Terhadap Anggota Federasi Serikat Pekerja Pertanian Dan Perkebunan Provinsi Riau Yang Dalam Proses Pemutusan Hubungan Kerja (PHK)
}

\author{
Robert Libra ${ }^{\mathrm{a}}$, Zulkarnaen Noerdin ${ }^{\mathrm{b}}$ \\ ${ }^{a}$ Fakultas Hukum, Universitas Lancang Kuning, Pekanbaru, Indonesia, Email: robertlibra@unilak.ac.id \\ ${ }^{\mathrm{b}}$ Fakultas Hukum, Universitas Lancang Kuning, Pekanbaru, Indonesia, Email: zulkarnaennoerdin65@ gmail.com
}

\section{Article Info}

\section{Article History:}

Received : 01-01-2020

Revised : 20-01-2020

Accepted : 10-02-2020

Published : 28-02-2020

\section{Keywords:}

Keyword 1 : Enterpreneur

Keyword 2 : Workers

Keyword 3 : Work Termination

\section{Informasi Artikel}

\begin{tabular}{ll}
\hline \multicolumn{3}{l}{ Histori Artikel: } \\
Diterima & $: 01-01-2020$ \\
Direvisi & $: 20-01-2020$ \\
Disetujui & $: 10-02-2020$ \\
Diterbitkan & $: 28-02-2020$
\end{tabular}

\section{Kata Kunci:}

Kata Kunci : Pengusaha

Kata Kunci : Pekerja

Kata Kunci : Pemutusan

Hubungan Kerja

\begin{abstract}
The problem examined in this study is the Implementation of Employer Obligations to Workers of Members of the Federation of Agricultural and Plantation Workers of Riau Province who are in the process of terminating their employment. This research method is carried out directly in the field according to the type of sociological legal research. The results showed that the implementation of regulations regarding the Obligations of Employers to Workers of the Members of the Federation of Agricultural and Plantation Workers in Riau Province who are currently in the process of termination of employment has not achieved maximum results. Factors that hinder the implementation of regulations on Employer Obligations to Workers of Members of the Federation of Agricultural and Plantation Workers of Riau Province who are currently in the process of termination of employment are: applicable law, time that is not optimal in solving problems at court level, absence of government programs in resolution the problem. The efforts made are in the form of preventive and representative actions
\end{abstract}

\begin{abstract}
Abstrak
Pelaksanaan Kewajiban Pengusaha terhadap Pekerja Anggota Federasi Serikat Pekerja Pertanian dan Perkebunan Provinsi Riau yang sedang dalam proses Pemutusan Hubungan Kerja. Metode penelitian ini dilakukan secara langsung dilapangan sesuai dengan jenisnya penelitian hukum sosiologis. Hasil penelitian diketahui bahwa pelaksanaan regulasi tentang Kewajiban Pengusaha terhadap Pekerja Anggota Federasi Serikat Pekerja Pertanian dan Perkebunan Provinsi Riau yang sedang dalam proses Pemutusan Hubungan Kerja belum mencapai hasil yang maksimal. Faktor yang menghambat pelaksanaan regulasi tentang Kewajiban Pengusaha terhadap Pekerja Anggota Federasi Serikat Pekerja Pertanian dan Perkebunan Provinsi Riau yang sedang dalam proses Pemutusan Hubungan Kerja adalah berupa: hukum yang berlaku, waktu yang tidak maksimal dalam penyelesaian masalah di tingkat pengadilan, tidak adanya program pemerintah dalam penyelesaian masalah tersebut. Upaya yang dilakukan adalah berupa tindakan preventif dan representatif
\end{abstract}




\section{PENDAHULUAN}

Permasalahan Pemutusan Hubungan Kerja (PHK) di Indonesia sangat marak terjadi, pengusaha sebagai pihak pemberi kerja terkadang kurang memahami bagaimana kewajibannya terhadap pekerja yang diberhentikan. Tenaga kerja juga banyak yang kurang memahami haknya ketika di PHK. Pemutusan Hubungan Kerja ini berdasarkan ketentuan Pasal 150 Undang-Undang No.13 Tahun 2003 meliputi PHK yang terjadi di badan usaha yang berbadan hukum atau tidak, milik orang perseorangan, milik persekutuan atau badan hukum, baik milik swasta maupun milik negara, maupun usaha-usaha sosial dan usaha-usaha lainnya yang mempunyai pengurus dan memperkerjakan orang lain dengan membayar upah atau imbalan dalam bentuk lain. ${ }^{1}$ Asosiasi pekerja merupakan pihak yang memahami tentang ini, maka ketika di PHK oleh pengusaha tenaga kerja meminta bantuan kepada asosiasi untuk mewakili mereka supaya hak dan kewajibannya terpenuhi dengan baik. Dan tindakan asosiasi pekerja/serikat pekerja sebagai kuasa dari tenaga kerja dijamin oleh Peraturan Perundangundang di Indonesia.

Serikat pekerja/serikat buruh adalah organisasi yang dibentuk dari,oleh,dan untuk pekerja/buruh baik diperusahaan maupun diluar perusahaan, yang bersifat bebas, terbuka, mandiri, demokratis, dan bertanggungjawab guna memperjuangkan, membela serta melindungi hak dan kepentingan pekerja/buruh serta meningkatkan kesejahteraan pekerja/buruh dan keluarganya. ${ }^{2}$

Federasi Serikat Pekerja Pertanian dan Perkebunan adalah gabungan Serikat Pekerja Pertanian dan Perkebunan yang terdaftar di Dinas Tenaga Kerja dan Transmigrasi Provinsi Riau Nomor: 05/PD.FSPPP.SPSI/DTK/04/2009 yang didirikan berdasarkan akta pendirian Perkumpulan Serikat Pekerja Pertanian dan Perkebunan Serikat Pekerja seluruh Indonesia (SPPP-SPSI) dari Notaris Netty Maria Machdar, S.H Nomor 72 Tanggal 13 Desember 2016. Hasil wawancara awal dengan Bapak Amrul Hadi Dalimunthe sebagai ketua serikat, Anggotanya Federasinya adalah Lebih Kurang 45.000 (empat puluh lima ribu) orang yang terdiri dari karyawan atau pekerja dari perusahaan Pertanian dan perkebunan di Provinsi riau. Selanjutnya yang rata-rata perkara pemutusan hubungan kerja bagi anggota Federasi serikat

\footnotetext{
${ }^{1}$ Asri Wijayanti, Hukum Ketenagakerjaan Pasca Reformasi. Jakarta : Sinar Grafika, 2010, Hlm, 158

${ }^{2}$ Zaeni Asyhadie dan Rahmawati Kusuma, Hukum Ketenagakerjaan (Dalam Teori dan Praktik Indonesia). Jakarta Timur : Prenadamedia, 2019, Hlm, 153.
} 
berperkara yang diwakili oleh ketua atau pengurus serikat yang sampai ke pengadilan hubungan industrial lebih kurang 10 perkara per tahun.

Dalam setiap berperkara Pemutusan Hubungan Kerja Pengurus PD.FSPPP.SPSI selalu meminta kepada pengusaha untuk melaksanakan kewajibannya terhadap karyawan, karena urgen, akan tetapi tidak pernah diberikan Pengusaha. ${ }^{3}$

Regulasi di Indonesia telah memberikan Pengaturan tentang kewajiban Pengusaha kepada pekerja dalam hal Pemutusan Hubungan Kerja. Hal ini tertuang dalam Pasal 155 Undang-undang Nomor 13 tahun 2003 tentang Ketenagakerjaan Menyatakan:

1. Pemutusan hubungan kerja tanpa penetapan sebagaimana dimaksud dalam Pasal 151 ayat (3) batal demi hukum.

2. Selama putusan lembaga penyelesaian perselisihan hubungan industrial belum ditetapkan, baik pengusaha maupun pekerja/buruh harus tetap melaksanakan segala kewajibannya.

3. Pengusaha dapat melakukan penyimpangan terhadap ketentuan sebagaimana dimaksud dalam ayat (2) berupa tindakan skorsing kepada pekerja/buruh yang sedang dalam proses pemutusan hubungan kerja dengan tetap wajib membayar upah beserta hak-hak lainnya yang biasa diterima pekerja/buruh.

Pasal 17 Kepmenakertrans Nomor: Kep-150/MEN/2000 menyatakan sebelum ijin pemutusan Hubungan Kerja diberikan Oleh Panitia Daerah dan Panitia Pusat sedangkan Pengusaha tidak melakukan skorsing terhadap Pekerja maka Pengusaha dan Pekerja harus tetap memenuhi segala kewajibannya.

Proses berperkara dalam Bidang Ketenagakerjaan sampai tingkat kasasi dimahkamah agung memakan waktu 80 hari atau dalam praktek bisa lebih, sementara pada waktu tersebut karyawan yang sedang di PHK oleh Perusahaan Pertanian dan Perkebunan di Provinsi Riau tidak menerima Upahnya. Wawancara awal penulis dengan pengurus Indonesia Plantation And Agriculture Workers Federation (Federasi Serikat Pekerja Pertanian dan Perkebunan PD.FSPPP.SPSI) Bapak Hadrizon mengatakan dalam Proses Berperkara di Pengadilan Hubungan Industrial tersebut anggota kami ada yang bekerja menjadi tukang ojek, ada yang menjadi kuli bangunan untuk memenuhi nafkah keluarganya, dan ada pula yang pindah

\footnotetext{
3 Hasil wawancara dengan Bapak Amrul Hadi Dalimunthe sebagai ketua serikat pekerja pertanian dan perkebunan Provinsi Riau
} 
lansung bekerja ke Perusahaan lain. Jangka waktu berperkara yang hampir 3 (tiga) bulan membuat tenaga kerja terpaksa mencari jalan hidup yang lain untuk bertahan hidup.

Berdasarkan uraian diatas maka penelitian ini diberi judul: Kewajiban Pengusaha terhadap Anggota Federasi Serikat Pekerja Pertanian dan Perkebunan Provinsi Riau yang dalam Proses Pemutusan Hubungan Kerja (PHK). Untuk membahas dan menganalisis penyebab mengapa Pengusaha sangat sulit untuk melaksanakan kewajiban terhadap tenaga kerja yang sedang dalam proses PHK.

\section{ANALISIS DAN PEMBAHASAN}

Pelaksanaan Kewajiban Pengusaha terhadap Pekerja Anggota Federasi Serikat Pekerja Pertanian dan Perkebunan Provinsi Riau.

Pasal 96 Undang-undang Nomor 2 tahun 2004 menyebutkan hakim harus mengeluarkan putusan sela di sidang pertama atau setidaknya sidang kedua. Mengeluarkan putusan sela di dua tahap itu juga dinilainya terburu-buru dan tidak adil, karena tidak memberi salah satu pihak hak jawabnya. Karena dalam praktek, agenda di sidang pertama ialah pembacaan gugatan. Apakah majelis akan menetapkan putusan sela tanpa memberi kesempatan kepada lawannya untuk menjawab. Sidang Peradilan hubungan industrial yang dibatasi jangka waktunya yakni 50 hari juga membuat hakim belum ingin mengeluarkan putusan sela. Kalaupun ada putusan sela perlu pembuktian yang agendanya pada sidang ketiga dan keempat ujarnya. Meskipun dalam perkara tersebut pengusaha jelas-jelas mengakui tidak membayar, menurutnya masih perlu ada pembuktian. ${ }^{4}$

Hasil Wawancara dengan Ketua Federasi Serikat Pekerja Pertanian dan Perkebunan Serikat Pekerja Seluruh Indonesia (SPSI) Provinsi Riau Bapak Amrul Hadi Dalimunte dan Dari beberapa Putusan Pengadilan yang penulis ambil berdasarkan observasi penelitian yang dilakukan pada Lokasi Penelitian didapatkan data:

\begin{tabular}{|l|l|l|l|l|}
\hline No & Nomor Perkara & Penggugat & Tergugat & Keterangan \\
\hline 1 & 63/Pdt. & Budi Edwin & PT. Jatim Jaya & Hakim Menolak untuk \\
& Sus.PHI/2018/PN.Pbr & & Perkasa & $\begin{array}{l}\text { Menjatuhkan Putusan } \\
\text { berupa Perintah kepada } \\
\end{array}$ \\
& & & & Pengusaha supaya \\
\hline
\end{tabular}

\footnotetext{
${ }^{4}$ https://www.hukumonline.com/berita/baca/hol17282/upah-pekerja-selama-proses-phk-seringkali-tak-dibayar/ diakses tanggal 31 Oktober 2020
} 


\begin{tabular}{|c|c|c|c|c|}
\hline & & & & $\begin{array}{l}\text { membayarkan } \\
\text { kewajibannya yang } \\
\text { berjalan. }^{5}\end{array}$ \\
\hline 2 & 685 K/Pdt.Sus-PHI/2016 & $\begin{array}{l}\text { Jumadi } \\
\text { Siregar }\end{array}$ & $\begin{array}{l}\text { PT. Bina Fitri } \\
\text { Jaya }\end{array}$ & $\begin{array}{l}\text { Hakim Menolak untuk } \\
\text { Menjatuhkan Putusan } \\
\text { berupa Perintah kepada } \\
\text { Pengusaha supaya } \\
\text { membayarkan } \\
\text { kewajibannya yang } \\
\text { berjalan. }^{6}\end{array}$ \\
\hline 3 & 02/Pdt.sus.PHI/2016/PN.Pbr & $\begin{array}{l}\text { Agus } \\
\text { Warsito, } \\
\text { Rahmat, } \\
\text { Muhammad } \\
\text { Yayang }\end{array}$ & $\begin{array}{l}\text { PT. Inti } \\
\text { Kamparindo } \\
\text { Sejahtera }\end{array}$ & $\begin{array}{l}\text { Hakim Menolak untuk } \\
\text { Menjatuhkan Putusan } \\
\text { berupa Perintah kepada } \\
\text { Pengusaha supaya } \\
\text { membayarkan } \\
\text { kewajibannya yang } \\
\text { berjalan. }^{7}\end{array}$ \\
\hline 4 & 492 K/Pdt.Sus-PHI/2015 & $\begin{array}{l}\text { Abdul } \\
\text { Lumban } \\
\text { Gaol, } \\
\text { Zulkarnaen } \\
\text { Saun Kadir }\end{array}$ & $\begin{array}{l}\text { PT. Inti } \\
\text { Kamparindo } \\
\text { Sejahtera }\end{array}$ & $\begin{array}{l}\text { Hakim Menolak untuk } \\
\text { Menjatuhkan Putusan } \\
\text { berupa Perintah kepada } \\
\text { Pengusaha supaya } \\
\text { membayarkan } \\
\text { kewajibannya yang } \\
\text { berjalan. }^{8}\end{array}$ \\
\hline 5 & $\begin{array}{l}\text { 30/Pdt.Sus-PHI/2017/PN } \\
\mathrm{Pbr}\end{array}$ & $\begin{array}{l}\text { Saut } \\
\text { Hutagalung }\end{array}$ & $\begin{array}{lr}\text { PT. Pusaka } \\
\text { Megah } \quad \text { Bumi } \\
\text { Nusantara }\end{array}$ & $\begin{array}{l}\text { Hakim Menolak untuk } \\
\text { Menjatuhkan Putusan } \\
\text { berupa Perintah kepada } \\
\text { Pengusaha supaya } \\
\text { membayarkan }\end{array}$ \\
\hline
\end{tabular}

\footnotetext{
${ }^{5}$ Putusan Nomor: 63/Pdt. Sus.PHI/2018/PN.Pbr

${ }^{6}$ Putusan Nomor :685 K/Pdt.Sus-PHI/2016

${ }^{7}$ Putusan Nomor 02/Pdt.sus.PHI/2016/PN.Pbr

${ }^{8}$ Putusan Nomor 492 K/Pdt.Sus-PHI/2015
} 


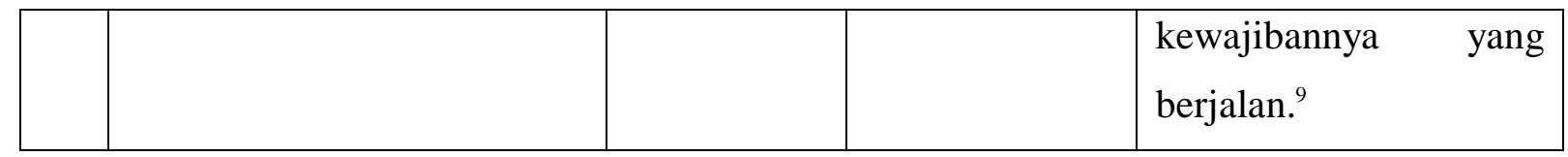

Data Putusan diperoleh dari: Indonesia Plantation And Agriculture Workers Federation Provinsi Riau. ${ }^{10}$

Dari 5 tabel diatas menunjukkan sangat sulit untuk dikabulkan permintaan Hakim untuk Menjatuhkan Putusan sela berupa Perintah kepada Pengusaha supaya membayarkan kewajibannya yang berjalan dari Penggugat di Pengadilan Hubungan Industrial Pekanbaru terkait dengan Perintah kepada pengusaha untuk Pembayaran Upah sebelum Perkara perselisihan Hubungan Industrial di Putus. Hasil wawancara dengan Bapak Ruzaini Pensiunan Disnaker Provinsi Riau Menyatakan Pernah Putusan Sela itu terkabul di Pengadilan Hubungan Industrial pekanbaru akan tetapi terkait dengan Kewenangan Absolut dari Pengadilan Hubungan Industrial.

Putusan Sela dijatuhkan sehubungan dengan adanya tuntutan provisional, yaitu suatu tuntutan yang sifatnya mendesak untuk segera diambil tindakan. Putusan sela bukan merupakan putusan akhir walaupun harus diucapkan dalam persidangan juga. ${ }^{11}$ Dalam hal ini pengusaha berkewajiban membayar upah terhadap pekerja yang sedang dalam Proses Pemutusan Hubungan Kerja. Tindakan pengusaha yang tidak melaksanakan kewajibannya terhadap hak-hak pekerja bisa berbahaya bagi kelangsungan hidup pekerja dan keluarganya, maka diperlukan Putusan Sela.

Pengusaha yang melakukan Pemutusan Hubungan Kerja kepada Tenaga Kerja tidak mempekerjakan ataupun melakukan skorsing terhadap pekerja serta tidak memberikan Upah serta hak-hak lainnya selama putusan Pengadilan Hubungan Industrial belum ditetapkan, walau Pemutusan Hubungan Kerja (PHK) yang dilakukan oleh pengusaha adalah secara sepihak tanpa adanya penetapan dari Pengadilan Hubungan Industrial.

Berdasarkan ketentuan Pasal 2 Peraturan Pemerintah Nomor 78 Tahun 2015 Tentang Pengupahan, pekerja yang masih dalam proses Pemutusan Hubungan Kerja masih berhak atas upah, apabila Pemutusan Hubungan Kerja tersebut bukan dikarenakan Pekerja/Buruh

\footnotetext{
9 Putusan Nomor 30/Pdt.Sus-PHI/2017/PN Pbr

10 Hasil wawancara dengan Bapak Amrul Hadi Dalimunthe sebagai ketua serikat pekerja pertanian dan perkebunan Provinsi Riau

${ }^{11}$ Indra Afrita, Hukum Ketenagakerjaan dan Penyelesaian Sengketa Hubungan Industrial di Indonesia.

Yogyakarta: Absolute Media, 2015, Hlm.138
} 
meninggal dunia, adanya Persetujuan Bersama antara pekerja dengan pengusaha atau adanya penetapan Pengadilan Hubungan Industrial. ${ }^{12}$

Secara yuridis, kedudukan antara pengusaha dan tenaga kerja adalah sama. Dalam asas Equality Before the Law diinterpretasikan bahwa pengusaha dan tenaga kerja memiliki kedudukan yang sama dalam hukum. Meskipun demikian, secara ekonomi maupun secara sosial, kedudukan antara pengusaha dan tenaga kerja adalah berbeda. Dari sisi ekonomi, pengusaha memiliki kedudukan ekonomi yang lebih tinggi dari tenaga kerja. Pengusaha adalah orang yang mempunyai modal usaha dan berhak untuk menerima tenaga kerja sesuai dengan persyaratan yang telah ditetapkannya, sedangkan

Tenaga kerja adalah orang yang membutuhkan uang sehingga mengajukan lamaran pekerjaan kepada pengusaha untuk mendapatkannya. Sejalan dengan itu, dari sisi sosial, pengusaha jelas memiliki kedudukan sosial yang lebih terhormat dibandingkan dengan tenaga kerja. Oleh karena itu, hakikat dari hukum ketenagakerjaan adalah untuk melindungi tenaga kerja dari kemungkinan terjadinya penyalahgunaan kekuasaan oleh pengusaha. ${ }^{13}$

Pasal 155 Undang-undang Nomor 13 Tahun 2003 tentang Ketenagakerjaan memerintahkan pekerja dan pengusaha tetap menjalankan kewajibannya sampai ada penetapan Lembaga Penyelesaian Perselisihan Hubungan Industrial, termasuk Pengadilan Hubungan Industrial. Namun Pengusaha diperkenankan melakukan skorsing terhadap pekerja, dengan catatan tetap membayar upah pekerja. Untuk menjalankan Pasal 155 ini, hakim sebenarnya dapat menetapkan putusan sela yang memerintahkan membayar upah pekerja bila pengusaha tidak menjalankan kewajiban.

Sebagaimana diatur Pasal 96 Undang-Undang Nomor 2 Tahun 2004 tentang Penyelesaian Perselisihan Hubungan Industrial. Apalagi dengan resiko sita jaminan yang tidak bisa dilawan. Tidak pernah dikeluarkannya perintah ini memancing protes dari kalangan pekerja. Menurut Odie, ini masalah besar dan sangat melemahkan posisi buruh. beliau mencontohkan pekerja Sogo meski telah menang di pengadilan hubungan industrial mereka belum juga dibayar dan terpaksa mencari pekerjaan sampingan seperti jadi supir taksi, menjual gorengan, dan ngojek motor. sebenarnya pengusaha juga dirugikan saat harus mengeluarkan uang secara sekaligus saat Pemutusan hubungan kerja telah diputus oleh hakim. Karena, kalaupun pengusaha menang, mereka tetap harus mengeluarkan upah selama

\footnotetext{
${ }^{12}$ Pasal 2 Peraturan Pemerintah RI Nomor 78 Tahun 2015 Tentang Pengupahan

${ }^{13}$ R. Joni Bambang S. Hukum Ketenagakerjaan. Bandung: Pustaka Setia, 2013, Hlm 23
} 
proses. Selanjutnya Odie bercerita, pernah suatu kali dalam sidang pertama perkara PHK yang ditanganinya, ia mengajukan bukti-bukti antara lain berupa buku tabungan yang tidak ada transfer masuk. Kemudian menurutnya permintaan putusan selanya ditolak hakim, Ternyata itu tidak cukup kuat buat majelis hakim ujarnya. ${ }^{14}$

\section{Kendala dan Upaya dalam mengatasi Kendala dalam Pelaksanaan Kewajiban Pengusaha terhadap Pekerja Anggota Federasi Serikat Pekerja Pertanian dan Perkebunan Provinsi Riau.}

Kendala dan upaya mengatasinya dalam Pelaksanaan Kewajiban Pengusaha terhadap Pekerja Anggota Federasi Serikat Pekerja Pertanian dan Perkebunan Provinsi Riau., diantaranya:

1. Pengusaha memiliki pemahaman yang kurang baik tentang upah proses yang sebenarnya upah proses tersebut tetap ada selama proses pemutusan hubungan kerja,

2. Ketika Pekerja mangajukan Putusan sela tentang perintah kepada pengusaha untuk membayar upah proses Majelis Hakim tidak ingin terburu-buru dalam mengambil suatu keputusan karena ingin memperoleh jawaban dulu dari pihak pengusaha tentang duduk perkaranya,

3. belum adanya Program dari pemerintah dalam memberikan kebijakan terhadap tenaga kerja yang diputus upahnya secara sepihak oleh pengusaha karena sedang menjalani penyelesaian pemutusan hubungan kerja pada pengadilan hubungan industrial.

Upaya mengatasinya dalam Pelaksanaan Kewajiban Pengusaha terhadap Pekerja Anggota Federasi Serikat Pekerja Pertanian dan Perkebunan Provinsi Riau yang sedang dalam Proses Pemutusan Hubungan Kerja, diantaranya: Pengusaha memiliki pemahaman yang kurang baik tentang upah proses yang sebenarnya upah proses tersebut tetap ada selama proses pemutusan hubungan kerja, seharusnya pengusaha diundang oleh Pemerintah dalam hal ini Kementerian Tenaga Kerja terkait Pemahahaman Pemutusahan hubungan kerja apa saja hak dan kewajiban yang harus di lakukan.

Ketika Pekerja mangajukan Putusan Sela tentang perintah kepada pengusaha untuk membayar upah proses Majelis Hakim tidak ingin terburu-buru dalam mengambil suatu keputusan karena ingin memperoleh jawaban dulu dari pihak pengusaha tentang duduk perkaranya. Seharusnya ini tidak dianggap terburu-buru karena ini adalah hak dari tenaga

\footnotetext{
${ }^{14}$ www.hukumonline.com
} 
kerja. Willy dan Odie Hudiantoro pada hukumonline.com, Sekretaris Federasi Serikat Pekerja Mandiri yang cukup sering mendampingi pekerja di Pengadilan Hubungan Industrial Jakarta. Dalam praktek, menurut Willy pengusaha biasanya bersikap defensif soal upah sambil menunggu proses mediasi hingga ke putusan Pengadilan hubungan industrial. Kalau pengadilan kemudian mengabulkan untuk bayar upah baru Pengusaha bayar. Menurutnya, ini yang biasanya menjadi strategi pengusaha supaya tidak membayar bayar upah pekerja selama skorsing. Begitu kecenderungannya, daripada menskorsing dan harus bayar pengusaha lansung lakukan pemutusan hubungan kerja sepihak saja. Putusan sela sesuai Pasal 96 Undang-undang Nomor 2 tahun 2004 tentang Penyelesaian Perselisihan Hubungan Industrial, hanya dapat dipakai apabila pengusaha skorsing. Akan tetapi ketika Pengusaha tidak lagi membayarkan upah tenaga kerja dalam masa Pemutusan Hubungan kerja maka ini sangat merugikan pekerja seharusnya pengusaha tetap membayarkannya untuk keberlansungan ekonomi Pekerja. belum adanya sanksi yang tegas bagi majelis hakim dari komisi yudisial RI ketika keharusan putusan sela itu tidak dilakukan padahal sangat cukut bukti untuk bisa menjatuhkannya dan belum adanya Program dari pemerintah dalam memberikan kebijakan terhadap tenaga kerja yang diputus upahnya secara sepihak oleh pengusaha karena sedang menjalani penyelesaian pemutusan hubungan kerja pada lembaga .

Undang-undang Nomor 2 tahun 2004. Menurutnya Pasal 96 menyebutkan hakim harus mengeluarkan putusan sela di sidang pertama atau setidaknya sidang kedua. Legislatif dan praktek pengadilan tidak sejalan. Karena praktek punya acara dan agenda sidang. Mengeluarkan putusan sela didua tahap itu juga dinilainya terburu-buru dan tidak adil, karena tidak memberi salah satu pihak hak jawabnya. Karena dalam praktek, agenda di sidang pertama ialah pembacaan gugatan. Apakah majelis akan menetapkan putusan sela tanpa memberi kesempatan kepada lawannya untuk menjawab? Kalau begitu buat apa ada pengadilan kalau dalam sidang pertama dapat ditetapkan putusan sela. Sidang Pengadilan hubungan industrial yang dibatasi jangka waktunya yakni 50 (lima puluh hari) juga membuat hakim tidak ingin mengeluarkan putusan sela. Kalaupun ada putusan sela perlu pembuktian yang agendanya pada sidang ketiga dan keempat ujarnya. Meskipun dalam perkara tersebut pengusaha jelas-jelas mengakui tidak membayar, menurutnya masih perlu ada pembuktian. 
Seringkali pembayaran upah skorsing kepada buruh dalam proses pemutusan hubungan kerja dianggap tidak adil bagi pengusaha. ${ }^{15}$

Perselisihan antara pekerja/buruh dengan pihak pengusaha merupakan suatu hal yang tidak mudah untuk dicegah, karena perselisihan bias terjadi tanpa suatu pelanggaran. ${ }^{16}$ Pembayaran upah skorsing seringkali menjadi alasan peselisihan antara buruh dan pengusaha, karena perselisihan Pemutusan hubungan kerja akan menjadi beban baik dari segi biaya maupun waktu bagi pengusaha dan buruh. Dari segi biaya, pengusaha merasa sangat dirugikan jika harus membayar upah skorsing atau upah proses untuk jangka waktu yakni sampai putusan berkekuatan hukum tetap. Sementara itu, dari segi waktu pengusaha merasa dirugikan karena proses hukum dalam penetapan perselisihan hubungan industrial hingga ada putusan berkekuatan hukum tetap (inkracht) di Indonesia seringkali membutuhkan waktu yang cukup lama. Penafsiran terhadap jangka waktu yang harus dibayar oleh pengusaha kepada pekerja kemudian menjadi problematika hukum.

Belum adanya Program dari pemerintah dalam memberikan kebijakan terhadap tenaga kerja yang diputus upahnya secara sepihak oleh pengusaha karena sedang menjalani penyelesaian pemutusan hubungan kerja pada pengadilan hubungan industrial. Seharusnya ada peraturan Pemerintah untuk menjelaskan tentang bagaimana penafsiran dari Undangundang Nomor 13 tahun 2003 tentang ketenagakerjaan khususnya tentang kewajiban pengusaha mengenai Upah Proses.

\section{KESIMPULAN}

Pelaksanaan Kewajiban Pengusaha terhadap Pekerja Anggota Federasi Serikat Pekerja Pertanian dan Perkebunan Provinsi Riau yang sedang dalam Proses Pemutusan Hubungan Kerja dalam praktek tidak terlaksana, dikarenakan dari Perkara Penyelesaian Perselisihan Hubungan Industrial yang ditangani oleh Federasi Serikat Pekerja Pertanian dan Perkebunan Provinsi Riau selalu diajukan Putusan Sela Supaya Hakim Segera memerintahkan Pengusaha untuk membayar Upah akan tetapi tidak pernah dikabulkan hakim pengadilan Hubungan Industrial Pekanbaru.

Kendala dan upaya mengatasinya dalam Pelaksanaan Kewajiban Pengusaha terhadap Pekerja Anggota Federasi Serikat Pekerja Pertanian dan Perkebunan Provinsi Riau adalah

\footnotetext{
${ }^{15}$ https://www.hukumonline.com/berita/baca/hol17282/upah-pekerja-selama-proses-phk-seringkali-tak-dibayar/ diakses tanggal 31 Oktober 2020

${ }^{16}$ Payaman J.Simanjuntak, Manajemen Hubungan Industrial. Jakarta : Jala Pertama Aksara, 2009. Hlm.151
} 
Pengusaha memiliki pemahaman yang kurang baik tentang upah proses yang sebenarnya upah proses tersebut tetap ada selama proses pemutusan hubungan kerja, Ketika Pekerja mangajukan Putusan sela tentang perintah kepada pengusaha untuk membayar upah proses Majelis Hakim tidak ingin terburu-buru dalam mengambil suatu keputusan karena ingin memperoleh jawaban dulu dari pihak pengusaha tentang duduk perkaranya, belum adanya Program dari pemerintah dalam memberikan kebijakan terhadap tenaga kerja yang diputus upahnya secara sepihak oleh pengusaha karena sedang menjalani penyelesaian pemutusan hubungan kerja pada pengadilan hubungan industrial. Beberapa saran dari penelitian yang telah dilakukan, Seharusnya Pengusaha diundang oleh Pemerintah dalam hal ini Kementerian Tenaga Kerja terkait Pemahahaman Pemutusahan hubungan kerja apa saja hak dan kewajiban yang harus di lakukan, Seharusnya Mejelis Hakim dalam Perkara Pemutusan Hubungan Kerja lebih berani menjatuhkan Putusan berupa perintah kepada pengusaha untuk membayarkan upah proses kepada tenaga kerja dan Seharusnya ada Peraturan Pemerintah untuk menjelaskan tentang bagaimana penafsiran dari Undang-undang Nomor 13 tahun 2003 tentang ketenagakerjaan khususnya tentang kewajiban pengusaha tentang Upah Proses.

\section{DAFTAR PUSTAKA}

Adrian Sutedi, Hukum Perburuhan, Sinar Grafika, Volume 2, Jakarta, 2012.

Asri Wijayanti, Hukum Ketenagakerjaan Pasca Reformasi. Jakarta: Sinar Grafika, 2010.

Indra Afrita, Hukum Ketenagakerjaan dan Penyelesaian Sengketa Hubungan Industrial di Indonesia. Yogyakarta: Absolute Media, 2015.

Lalu Husni, Pengantar Hukum Ketenagakerjaan, Raja Grafindo Persada, Jakarta 2014.

Payaman J.Simanjuntak, Manajemen Hubungan Industrial. Jakarta : Jala Pertama Aksara, 2009.

R. Joni Bambang S. Hukum Ketenagakerjaan. Bandung: Pustaka Setia, 2013.

Zaeni Asyhadie dan Rahmawati Kusuma, Hukum Ketenagakerjaan (Dalam Teori dan Praktik Indonesia). Jakarta Timur : Prenadamedia, 2019.

Undang Undang Dasar Negara Republik Indonesia tahun 1945.

Undang undang Nomor 12 tahun 2011 tentang Pembentukan peraturan Perundang-undangan.

Undang Undang Nomor 13 tahun 2003 tentang Ketenagakerjaan.

Undang Undang Nomor 2 tahun 2004 tentang Penyelesaian Perselisihan Hubungan Industrial 
Peraturan Pemerintah Nomor 78 Tahun 2015 tentang Pengupahan.

https://www.hukumonline.com/berita/baca/hol17282/upah-pekerja-selama-proses-phkseringkali-tak-dibayar/ diakses tanggal 31 Oktober 2020. 